\title{
Effect of land use and land cover changes on water quality in the Nawuni Catchment of the White Volta Basin, Northern Region, Ghana
}

\author{
Abdulai A. Tahiru' ${ }^{1}$ Dzigbodi A. Doke ${ }^{1} \cdot$ Bernard N. Baatuuwie $^{1}$ \\ Received: 15 May 2019 / Accepted: 26 June 2020 / Published online: 31 July 2020 \\ (c) The Author(s) 2020
}

\begin{abstract}
Pollution of freshwater resources is gaining global attention due to increasing freshwater stress and scarcity. This study assessed land use and land cover changes (LULCC) in the Nawuni Catchment of the White Volta Basin and how the change affects water quality in the area. Satellite images from Landsat Thematic Mapper and Landsat 8 Operational land imager of the Nawuni Catchment of the White Volta Basin were acquired and used for this study. These images were analysed to ascertain the influence of land use and land cover changes on water quality parameters such as turbidity, ammonia and total coliform counts for a 10-year period (2007 to 2017). The results of LULCC revealed an increased expanse of grassland/ farmland (4.1\%), settlement $(0.1 \%)$, bare land (9.4\%) and closed savannah $(1.2 \%)$, whilst opened savannah (14.7\%) and water body $(0.1 \%)$ recorded a decreasing trend. The study showed an increase in the levels of turbidity and ammonia and a decrease in total coliforms over the study period (2007 to 2017). The study also revealed a positive relationship between LULC categories and water quality parameters, implying that LULCC contribute to the change in water quality in the area. The study therefore recommends frequent water quality monitoring and LULC planning and management to curb pollution of the river basin.
\end{abstract}

Keywords Land use and land cover change $\cdot$ Nawuni Catchment $\cdot$ Water quality $\cdot$ Water pollution $\cdot$ White Volta Basin

\section{Introduction}

Water pollution is one of the several critical issues facing the world in both developed and developing countries (Chaudhry and Malik 2017). Surface water resources around the world are under increasing threats of pollution especially rivers (Mul et al. 2015). The quality of surface water is important for various purposes such as domestic, industrial, agriculture uses (Nagaraju et al. 2014) and for disease prevention (Nabeela et al. 2014). The quality of water resources is affected by natural and anthropogenic activities (Matshakeni 2016) which may render it less valuable for human use.

Studies have shown that natural and human activities have resulted in land use and land cover (LULC) changes which

Abdulai A. Tahiru

atahiru@uds.edu.gh

Faculty of Natural Resources and Environment, University for Development Studies, Nyankpala Campus, Tamale, Ghana affects the services provided by the riparian ecosystem services (Chu et al. 2013; Wagner et al. 2013; Khan et al. 2017). Anthropogenic activities such as agriculture, deforestation and urbanization have been identified as the main drivers of land use and land cover change which affects the quality of water bodies (Khan et al. 2015; Olusola et al. 2018). These activities singularly or jointly impact the quality of water resources. The land use, therefore, within a watershed has a great impact on the water quality and quantity of rivers ( $\mathrm{Li}$ et al. 2014).

The knowledge of the relationship between land use and water quality of rivers helps in identifying threats to water quality. Identifying this relationship is relevant for effective and sustainable surface water quality management especially in minimizing the pollutant loads in the water body (Ding et al. 2015).

In many Sub-Saharan countries, surface water is mostly used for domestic, industrial and agricultural purposes. These surface water bodies are threatened due to land degradation. This is because majority of the rural poor in these vulnerable regions depend heavily on natural resources 
including land for their livelihood (Nkonya et al. 2016). It is estimated that about $28 \%$ of the 924.7 million people in Sub-Sahara Africa (SSA) live in areas that have experienced degradation since 1980s (Le et al. 2014; UN 2014). The grasslands which constitute $40 \%$ of the land area suffered the most severe land degradation (Le et al. 2014). It has been reported that about $26 \%$ of forestland and $12 \%$ of cropland also experienced degradation (Nkonya et al. 2011). The degradation of these land resources would definitely have a negative impact on quality of surface water resources such as rivers and streams in the region.

There is the need to appraise the quality of the surface water to offer guidelines on maintaining a safe and healthy environment for human and ecosystem functioning in the face of increasing demand for freshwater. Ghana has abundant surface water resources. These include the Volta River System, Coastal River System and the South-Western River System (UNEP-GEF Project 2013; McCartney et al. 2012). These water resources serve as important sources of freshwater for domestic, agricultural and industrial purposes. Despite their importance to socio-economic development and transformation in the country, these water resources suffer deterioration of quality and quantity as a result of human activities such land use changes as well as poor and inadequate sanitation facilities (Mul et al. 2015), illegal mining (Doke and Gohlke 2014; WRC 2012; Gyawu Asante 2012) and dumping of waste into or near water courses (Gyamfi et al. 2012).

Furthermore, over $60 \%$ of the population depends directly and indirectly on agricultural land for livelihoods and are mostly found in and around the river basins. This resulted in land use and land cover alterations that will have negative consequences in the river basins (Ayivor and Gorden 2012; Ellis and Pontius 2007). The unsustainable methods of land cultivation around these water resources also lead to soil erosion and hence the deterioration of river water quality due to sedimentation (Ayivor and Gorden 2012). Nutrients discharge through inappropriate use of agrochemicals, and bush burning may also result in eutrophication and high nutrient load in river bodies (Ayivor and Gorden 2012; IUCN 2012; UNEP-GEF Project 2010; WRC 2012) which will also impact water quality.

In the Northern Region of Ghana, the White Volta Basin (WVB) which serves as the main source of water for agriculture and domestic purposes is under increasing threat due to pollution (WRC 2012). Several studies which reported pollution of water in the WVB suggest that the threat is driven by inappropriate land use associated with increasing human population (Issaka and Ashraf 2017; UNEP-GEF Project 2013; Bossio et al. 2010). A research conducted by Abdul-Razak et al. (2010) found that turbidity, total coliform, faecal coliform and total iron in the basin exceeded the limits set out by the Ghana Water Quality Guidelines 2003 and WHO 2011 water quality standard guideline values for surface water. Ayisi et al. (2014) also reported high turbidity in the basin, whilst Bakobie et al. (2015) and Kpieta and Laari (2014) in similar studies found that surface water in the WVB is contaminated with coliform bacteria. These parameters are indicative of increasing human activities in and around the White Volta Basin.

The Nawuni sub-basin which is one of the important catchments of the WVB has been reported to be experiencing severe land degradation due to land use and cover changes (Baatuuwie 2015; Mul et al. 2015). Even though previous studies have reported poor quality of water in the WVB, few of the studies have looked at the variations in the water quality over the years in association with LULCC using geographic information system (GIS) and remote sensing technology along the sub-catchment area. GIS and remote sensing tools are powerful and effective technologies which can be used to investigate many environmental resource management problems such as water quality assessment, determining water availability and managing water resources on a local or regional scale (Khan et al. 2011, Ketata et al. 2011; Shabbir and Ahmad 2015). The study assessed the relationship between water quality variation and land use and land cover changes in the Nawuni Catchment of the White Volta Basin. The findings of this study provide information for policy makers and other stakeholders of the WVB at all levels to make an informed decision in managing the water resources within the basin. The findings also add to the body of literature in the area of water and land resources management for sustainability.

\section{Research methods and approach}

\section{Study area}

The Nawuni sub-basin (Fig. 1) which is a sub-basin of the White Volta Basin stretches from Latitude $9^{\circ} 87^{\prime} \mathrm{N}$ to $11^{\circ}$ $15^{\prime} \mathrm{N}$ and Longitude $0^{\circ} 5^{\prime} \mathrm{W}$ to $1^{\circ} 26^{\prime} \mathrm{W}$ (Baatuuwie 2015). The basin has a fairly low relief with few areas of moderate elevation in the north and east of the country. The mean elevation is about $200 \mathrm{~m}$, and the highest portion is about $600 \mathrm{~m}$. Nawuni sub-basin is the largest of the sub-basins of the WVB which drained the entire Upper East Region and $50 \%$ of the Northern region of Ghana. The main tributaries of the White Volta include those from the north of the country such as Nawuni, the Red Volta (Nazinon) and the Sissili rivers (WRC 2012).

The Nawuni sub-basin is characterized by soil that usually support agriculture. Crops grown include maize and rice (Awotwi et al. 2015; WRC 2012). The sparse vegetative cover associated with indiscriminate annual bush burning during the dry season exposes the soils to disturbances such 


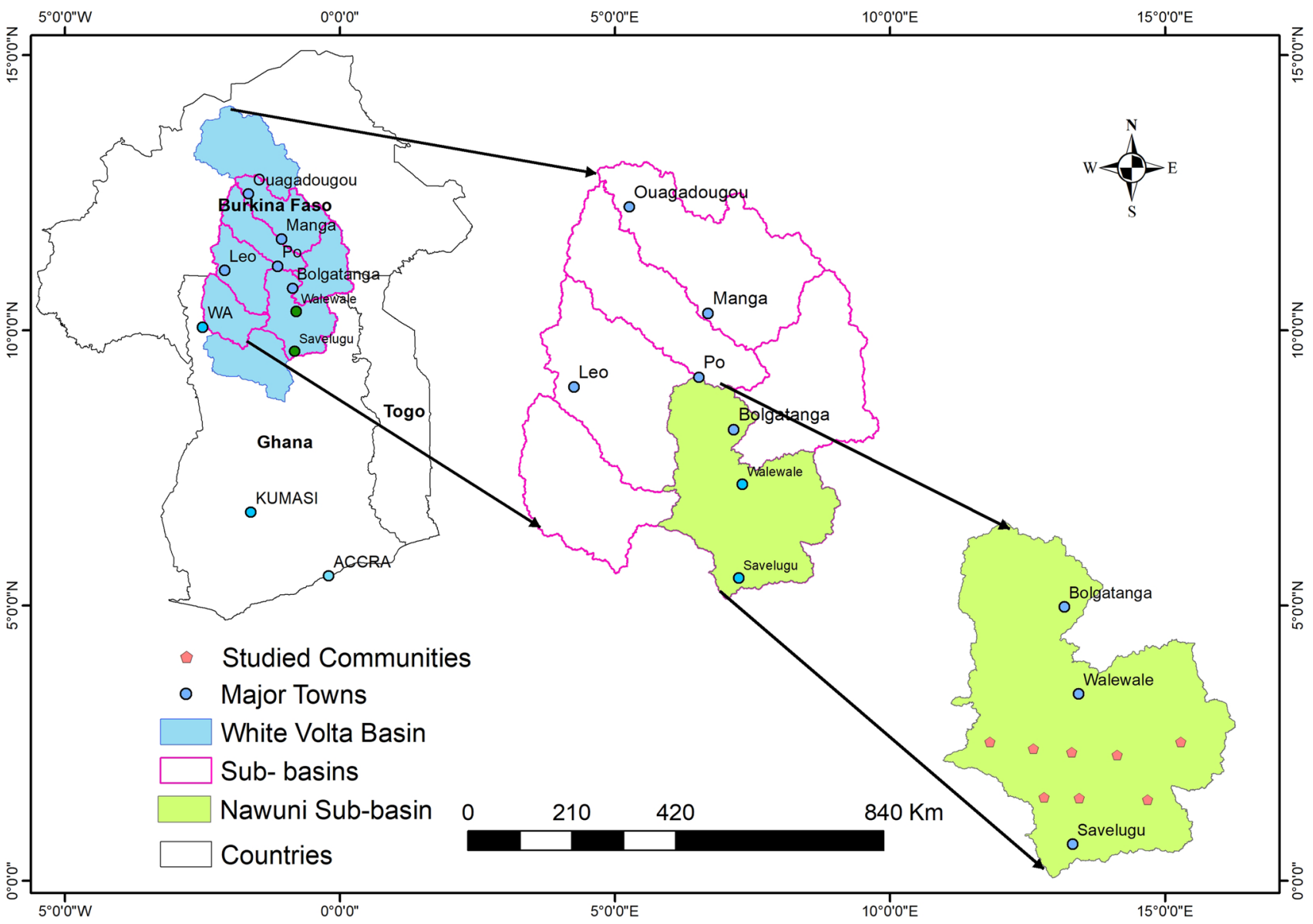

Fig. 1 Map of Nawuni Catchment area (Adopted from Baatuuwie 2015)

as erosion (WRC 2012). There are seasonal floods in the river basin and the common examples are that of the 2007, 2008, 2010 and 2012 (WRC 2012).

The main occupation of the people in the basin is agriculture such as crop and animal farming. Other economic activities of the people include fishing, lumber, charcoal production, agro-industry (for example, shea butter processing, rice, tomatoes and meat processing), mining (galamsey) and quarrying (WRC 2012).

\section{Data collection and analysis}

Surface water quality data of the Nawuni Catchment of the WVB were obtained from Ghana Water Company Limited (GWCL), Tamale, which span from 2007 to 2017. Out of 28 parameters measured by the company, three parameters were selected: one physical (turbidity), one chemical (ammonia) and one biological (total coliform for the study. The three parameters were chosen as representative of the other parameters for ease of analysis of the physical, chemical and biological quality of water.
Data were analysed using both quantitative and qualitative techniques. Average annual values (2007 to 2017) of water quality parameters were computed from monthly test values using Microsoft Excel 2016 edition. The results were then presented using descriptive statistics (mean, maximum, minimum and standard deviation). Analysis of variance (ANOVA) was done to test the variability of annual mean values of water quality parameters (ammonia, turbidity and total coliform). The test was done at $95 \%$ confidence level with the $P$ value of 0.05 .

Primary and secondary data were obtained for land use and land cover analysis. Reconnaissance field survey was carried out which preceded the ground truthing to be conversant with land use activities in the area. Primary data of geographic coordinates of areas of different land use types were gathered with the aid of Global Positioning System (GPS). These were used for training image classification algorithm as well as validating image classification results. Satellite images of Landsat Thematic Mapper (TM) for 2003, 2013 and Landsat data of the Landsat 8 Operational land imager (OLI) image for the year 2017 were accessed from the freely available website of the United States Geological 
Survey online imagery portal. Landsat images used for this study were geometrically corrected. Other geo-spatial data like shapefiles and topographic maps of the Nawuni Catchment and the WVB were obtained from the National Survey Department of Ghana and were used for the extraction and delineation of the study area. Image preprocessing operation was also performed. These include image geo-referencing (rectification), image enhancement (spectral and spatial) and false colour composite for simple visualization or discrimination of features in image. ERDAS IMAGINE 2010 software was used for image preprocessing, processing and post-classification analysis.

\section{Land use and land cover analysis}

In this study, both supervised and unsupervised classification methods were adopted. Unsupervised classification method was used first to have an idea regarding the overall land use and land cover cluster of pixels. Supervised classification method was then used with maximum likelihood classification algorithm. This algorithm unlike others considers the spectral variation within each category and the overlapping covering of the different classes of land use and land cover (Rientjes et al. 2011; Rawat and Manish 2015). Finally, the classified satellite images were verified for its accuracy or acceptance having gone through different mechanisms. This was to ensure that classes correspond against ground truth field samples obtained with GPS. The classified images were then imported to ArcMap 10.4 where composite maps were produced to show the land use and land cover of the study area.

Six land use and cover classes were identified for the Nawuni Catchment after preliminary field survey for the sub-basin. Areas in the basin which were inaccessible were surveyed using topographic maps and Google Earth. The following were categories of land use and cover classes and their descriptions:

(1) Closed savannah: area with high density of trees and shrubs with little or no disturbance; (2) opened savannah: areas with grasses with sufficient trees and shrubs which are widely spaced; (3) agricultural land/grassland: areas covered with predominantly small household mosaic agricultural farms, cultivated land and cultivable land as well as grasses or shrubs; (4) water body: area which holds water (lakes), rivers and marshy land; (5) settlement: areas covered with both towns and rural settlement; and (6) bare land: areas devoid of vegetation and tree cover.

To classify and verify these major land use and cover types, training sample points were prepared. On the number of ground truth data sampling, there is no single ideal number of ground truth data for image analysis. Scientists are subjective on the number of points collected (Muke and Haile 2018). However, what is recommended most is taking more coordinates for a single class of feature for creating signatures and accuracy assessment. The more points collected, the lower the standard error.

A total of 597 ground truths were collected during field survey using Global Positioning System (GPS) for these land use and cover categories. Additional information was collected by using google earth and interviewing elderly people who saw the changes happened in the area. From the 597 ground truths, $60 \%$ was used for training purpose holding out the $40 \%$ for validation.

After the LULC analysis, spearman correlation and multiple linear regression analyses were done to establish the relationship between water quality and LULCC with the aid of Statistical Package for the Social Sciences (SPSS) version 21 .

\section{Results and discussion}

\section{Water quality in the Nawuni Catchment of the WVB}

The mean turbidity of water in the Nawuni Catchment showed temporal variations over the 10 year period (Fig. 2). The highest annual mean turbidity (308 NTU) was recorded in 2012, whilst the least annual mean turbidity (83 NTU) representing 3.79\% was recorded in 2008. Annual average turbidity was found to be 199 NTU. It is evident that annual
Fig. 2 Annual temporal variation of turbidity of water in the Nawuni Catchment

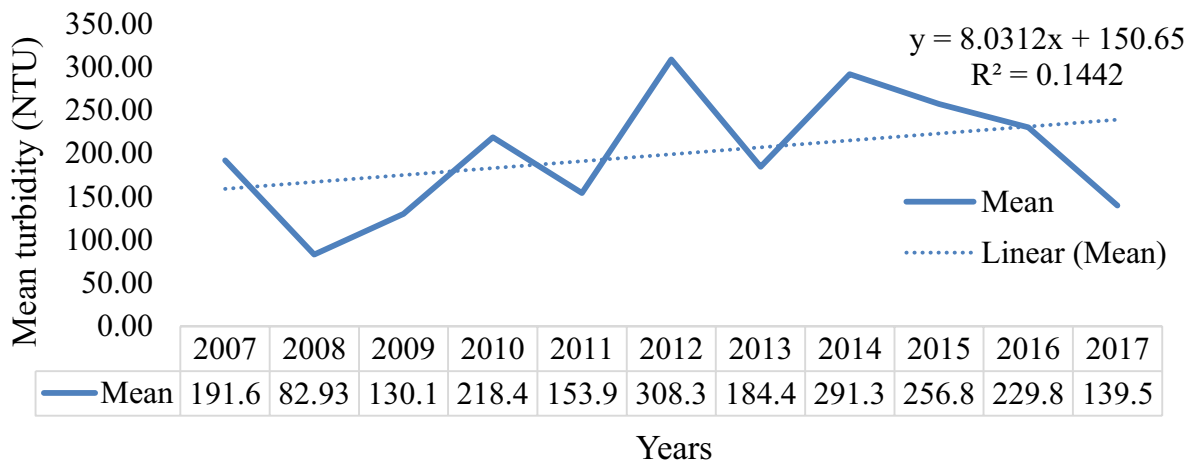


mean turbidity showed a rising and falling pattern over the period of study though the variations were not significantly different between years. Even though the turbidity concentration was within the normal surface water quality standard of 1-1000 NTU, the values, however, were above the World Health Organization (WHO)-recommended limit of 5 NTU for portability. The reason for the periodic high turbidity level could be attributed to the annual floods in the sub-basin (WRC 2012). Also farming along the river boundaries and activities like sand mining were prevalent in the area and could have contributed to the high turbidity in the basin due to surface run-off (WRC 2012). High turbidity limits the amount of sunlight and oxygen available for the survival of aquatic life and hence biological productivity in the area.

Ammonia is a naturally occurring chemical compound in water bodies, but high concentration of ammonia in water bodies is an indication of organic pollution, an important indicator of faecal pollution. Usually in areas of agriculture, high ammonia concentration in water is associated with the application of fertilizers. The study showed a temporal variation of ammonia in the Nawuni Catchment for the 10-year period. Ammonia concentration recorded ranged from 0.63 to $2.63 \mathrm{mg} / \mathrm{l}$ with an annual average of $1.69 \mathrm{mg} / \mathrm{l}$ (Fig. 3). The highest ammonia concentration was recorded in 2012 and 2017, whilst the lowest recorded in 2008. Usually in unpolluted water ammonia concentration is below $0.2 \mathrm{mg} / \mathrm{l}$ measured as $N$ (WHO 2011). The study showed that the mean concentration of ammonia of the water varied significantly across the 10 -year period $(P=0.001)$ (Fig. 3$)$. The high ammonia concentration in the White Volta Basin could be attributed to surface runoff from agricultural lands (WRC 2012). This is evident in the LULCC analysis as farmlands occupy large proportion of the land in the area (Table 1). Agriculture is the mainstay of the communities in the basin, and the extensive use of ammonia fertilizer could be the potential source. A high ammonia concentration in the water could lead to ammonia toxicity in aquatic animals.

The total coliform count in the water from the Nawuni Catchment for the 10-year period ranged from 950.00 to $4843.20 \mathrm{cfu} / 1 \mathrm{ml}$ with an annual average of $2880.27 \mathrm{cfu} / 1 \mathrm{ml}$ (Fig. 4). The total coliform count was above the WHO-recommended standard of zero count for potability and for all purposes. The least coliform count was recorded in 2017, whilst the highest coliform concentration was recorded in
Fig. 3 Annual temporal variation of ammonia in the Nawuni Catchment

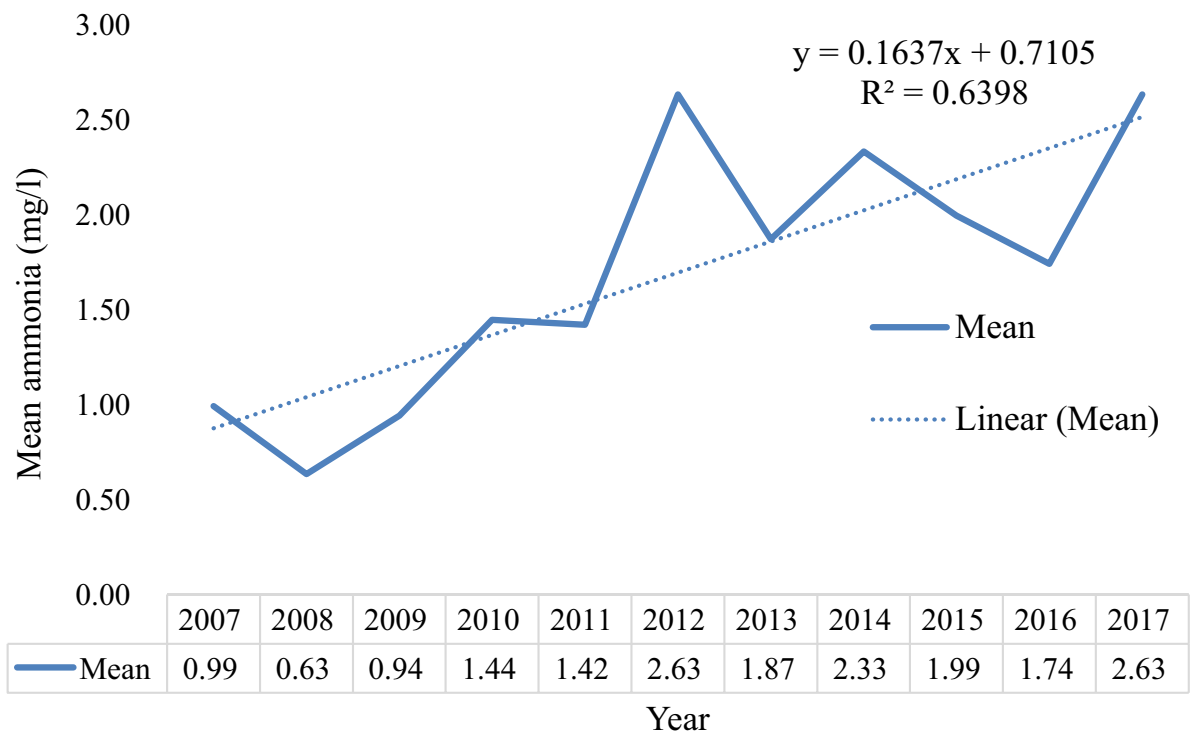

Table 1 Aerial coverage of LULC types in the Nawuni Catchment

\begin{tabular}{llll}
\hline LULC & 2003 ha $(\%)$ & 2013 ha $(\%)$ & 2017 ha $(\%)$ \\
\hline Built up/settlement & $3909.17(1.1)$ & $4680.99(1.3)$ & $5022.18(1.4)$ \\
Bare ground & $10,109.30(2.8)$ & $3154.95(0.9)$ & $36,988.70(10.3)$ \\
Closed savannah & $7222.48(2.0)$ & $39,510.50(11.1)$ & $43,852.00(12.3)$ \\
Opened savannah & $199,723.00(55.9)$ & $193,110.00(54.0)$ & $140,408.00(39.3)$ \\
Grassland/farmlands & $133,946.00(37.5)$ & $114,829.00(32.1)$ & $129,453.00(36.2)$ \\
Water body & $2179.51(0.6)$ & $2184.30(0.6)$ & $1745.91(0.5)$ \\
Total & $357,089.50$ & $357,469.70$ & $357,469.80$ \\
\hline
\end{tabular}

NB: Values in parentheses are percentage values 
Fig. 4 Annual temporal variation of total coliform in the Nawuni Catchment

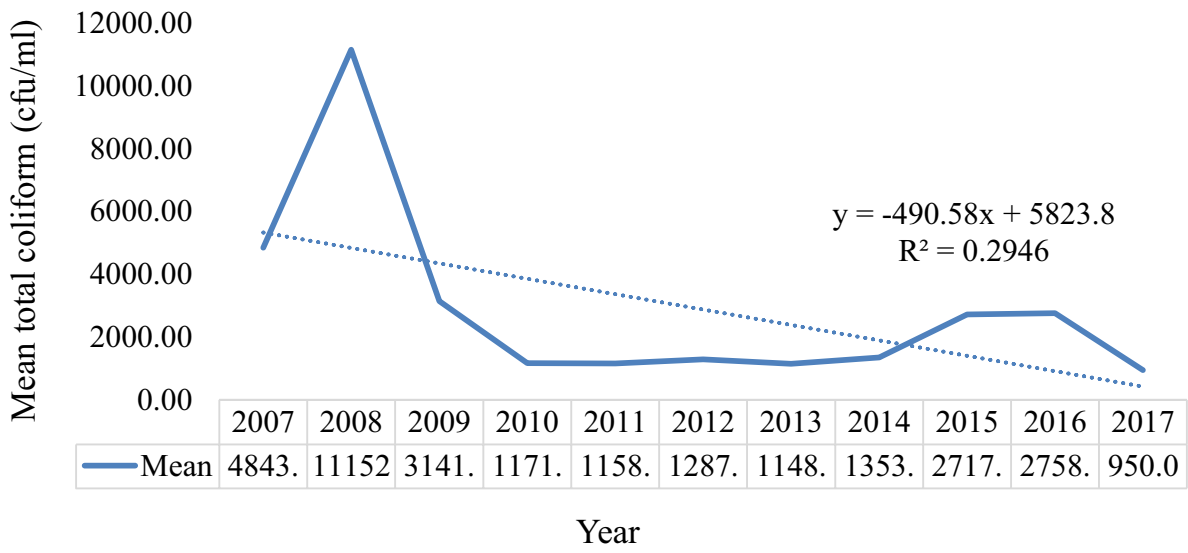

coupled with farm residues made the area favourable for animal grazing which might have led to their faecal matter finding their way into the water body through run off. Thus, the high densities of grazing animals in the area could also be an important source of coliforms in the river basin (WRC 2012; Awotwi et al. 2015). of total coliform could also be as a result of improper disposal of domestic and municipal waste. Furthermore, the large proportion of opened savannah in the area (Table 1)

2008. This could be attributed to the 2008 annual floods reported in the basin (WRC 2012) which might have washed coliform material into the river. The mean concentration of total coliform count in the water varied insignificantly across the 10-year period $(P=0.376)$ (Fig. 4). High concentrations

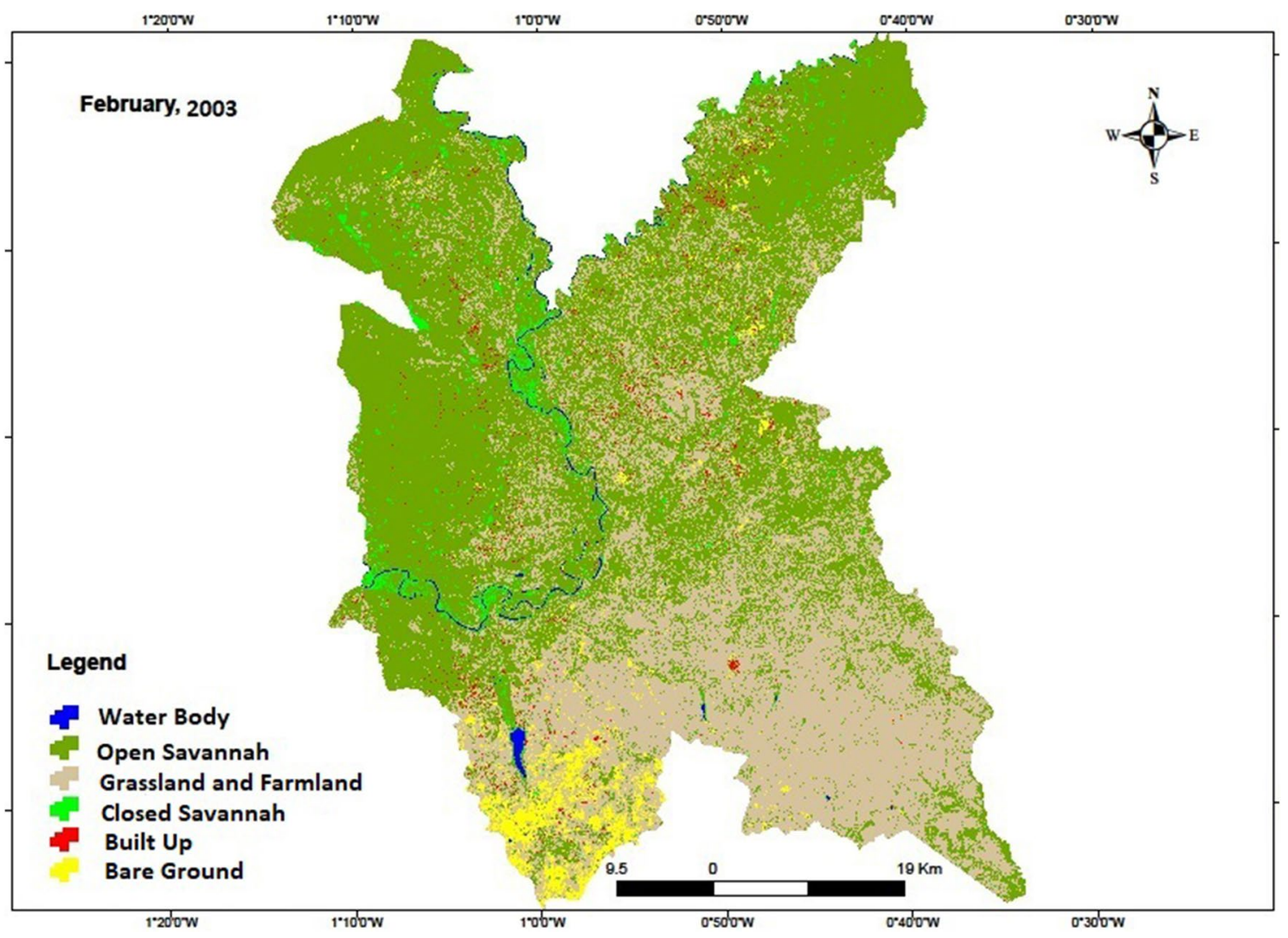

Fig. 5 Land use and land cover map of the Nawuni Catchment in 2003 


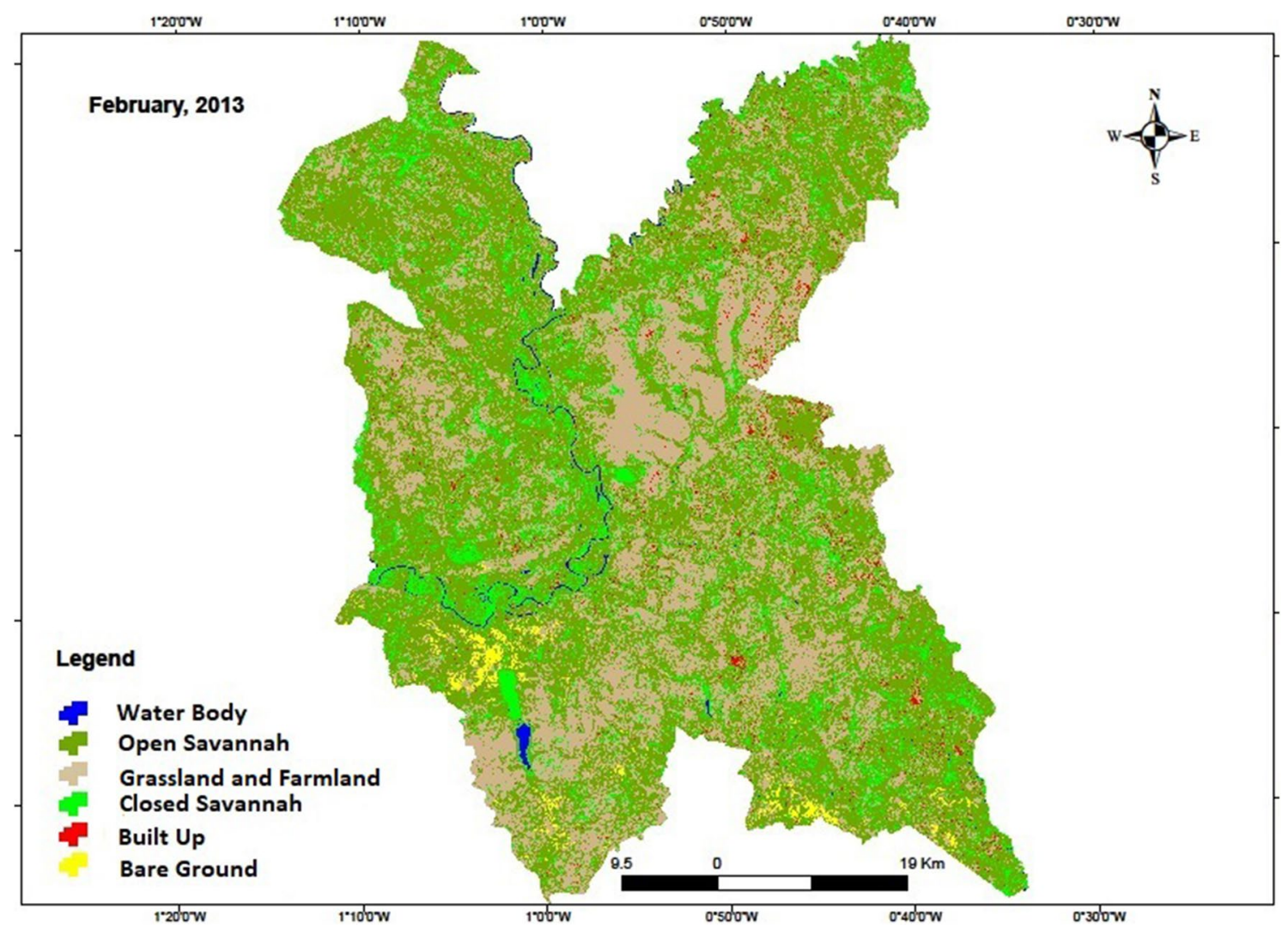

Fig. 6 Land use and land cover map of the Nawuni Catchment in 2013

\section{Land use and land cover change in the Nawuni Catchment}

LULCC was studied for the year 2003, 2013 and 2017 to determine the impact on water quality in the Nawuni Catchment. Six land use and land cover categories were identified: bare land, closed savannah, opened savannah, settlement, grassland/farmland and water body (Figs. 5, 6 and 7).

The present study revealed water body, settlement, closed savannah, opened savannah, bare land and grassland/farmland as the main land use and land cover types in the Nawuni Catchment of the White Volta Basin. In 2003, the Nawuni Catchment was predominantly occupied by opened savannah (199,723 ha) representing 55.9\% with grassland/farmland (133,946 ha) constituting $37.5 \%$ been the second dominant land use and land cover types in the catchment (Table 1). Water bodies occupied the smallest portion (2179.51 ha) representing $0.6 \%$ of the Nawuni catchment during the same period. Again in 2013, opened savannah and grassland/farmlands were still the two most dominant LULC types in the catchment with an aerial coverage of 193,110 ha (54.0\%) and 114,829 ha (32.1\%), respectively.

Assessment of the generated maps revealed a varying degree of changes in the composition of LULC categories in the study area over the 15 years (2003 to 2017). Opened savannah and grassland/farmlands remained the two dominant land use classes during the study periods $(2003,2013$, and 2017) (Table 2). The opened savannah reduced about 6613 ha (1.85\%) from 2003 to 2013 compared to 52,702 ha (49.59\%) from 2013 to 2017 . The rate of change (reduction) of the opened savannah between 2003 and 2013 stood at $1.01(1.85 \%)$ compared to $12.40(49.59 \%)$ between 2013 and 2017.

Similarly, there was a reduction in the grassland/farmland size by 19,117 ha (5.35\%) from 2003 to 2013 compared to an increase in grassland/farmlands by 14,624 ha $(13.76 \%)$ from 2013 to 2017 (Table 2). There was a 2.91 decrease rate of change in the grassland/farmland and a 3.44 increase rate of change from 2003 to 2013 and from 2013 to 2017, respectively. The reduction in aerial coverage of the grassland/ farmland during the past 14 years is approximately $51.44 \%$. Conversely, there was approximately $5.53 \%$ decrease in aerial extent of grassland/farmland during the first 10 years and an increment of the grassland/farmland during the last 4 years of the same study period to approximately $13.76 \%$. The reason for the reduction in opened savannah land could be due to the conversion of opened savannah to agricultural land (Muluneh and Arnalds 2011).

The degradation of the opened savannah could also due be to the increasing sand winning activities which are

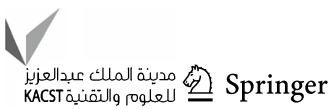




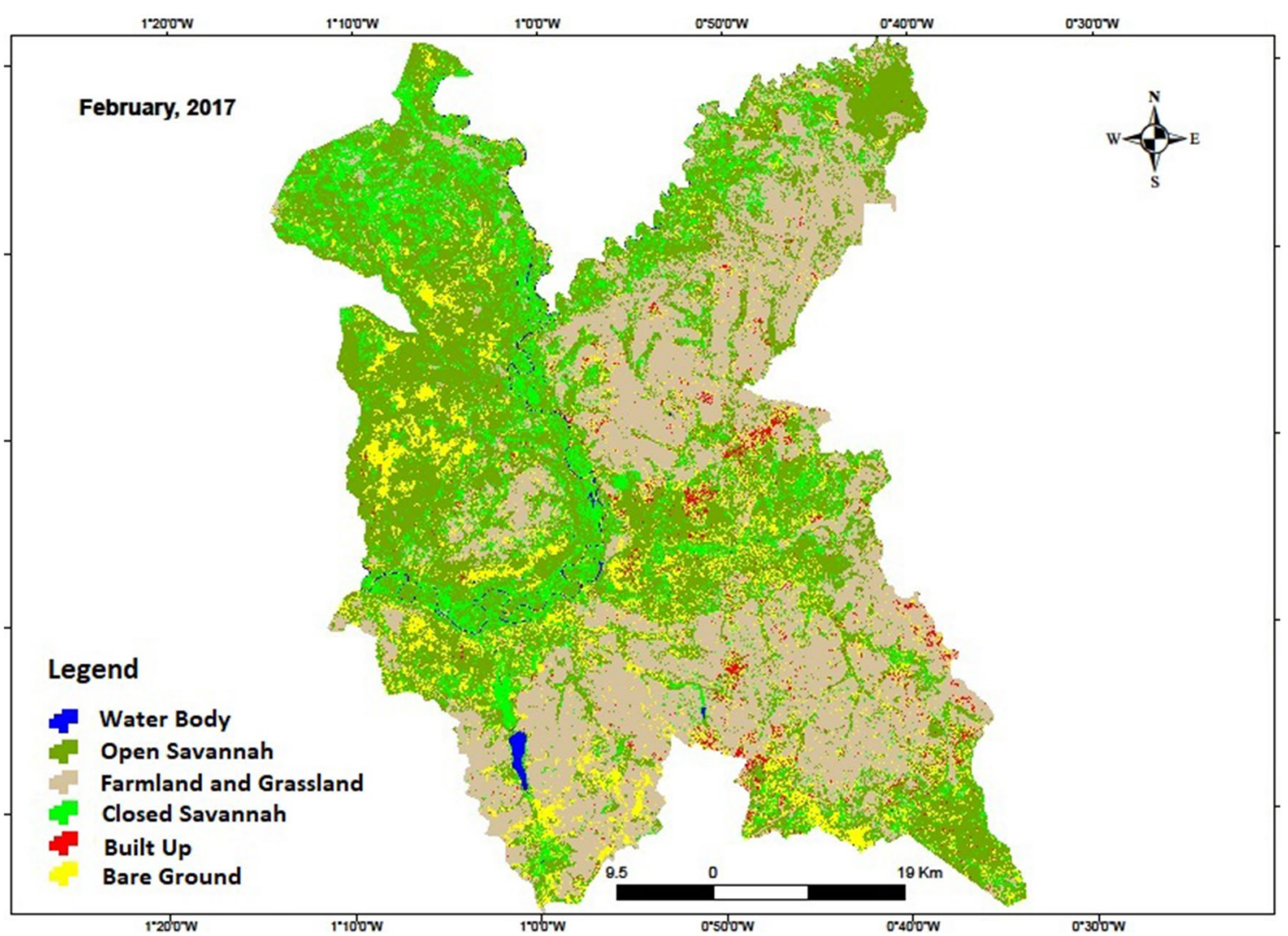

Fig. 7 Land use and land cover map of the Nawuni Catchment in 2017

Table 2 LULCC between 2003 and 2013 and between 2013 and 2017 in the Nawuni Catchment

\begin{tabular}{|c|c|c|c|c|c|c|}
\hline \multirow[t]{2}{*}{ LULC } & \multirow[t]{2}{*}{ Difference } & \multicolumn{2}{|l|}{ 2003-2013 } & \multirow[t]{2}{*}{ Difference } & \multicolumn{2}{|l|}{ 2013-2017 } \\
\hline & & Percentage change & Rate of change & & Percentage change & Rate of change \\
\hline Built up/settlement & 771.82 & 0.22 & 0.12 & 341.19 & 0.32 & 0.08 \\
\hline Bare ground & -6954.35 & -1.95 & -1.06 & $33,833.75$ & 31.83 & 7.96 \\
\hline Closed savannah & $32,288.02$ & 9.04 & 4.91 & 4341.50 & 4.08 & 1.02 \\
\hline Opened savannah & -6613.00 & -1.85 & -1.01 & $-52,702$ & -49.59 & -12.40 \\
\hline Grassland/farmlands & $-19,117.00$ & -5.35 & -2.91 & 14.62 & 13.76 & 3.44 \\
\hline Water body & 4.79 & 0.00 & 0.00 & -438.39 & -0.41 & -0.10 \\
\hline
\end{tabular}

predominantly turning the area into bare land as well as expansion of settlement in the opened savannah. Grassland/ farmland which was the second most dominant land cover in the Nawuni catchment occurred in the plains and along the rivers with few forest patches being distributed relatively along the main river course and in some plains of the catchment. This implies the expansion of the farmlands in the area resulted in the reduction of the opened savannah. This study also revealed that the Nawuni catchment has also witnessed an encroachment of opened savannah land for agricultural activities. This finding confirms earlier studies by Julian et al. (2016) and Pullanikkatil et al. (2015).

Built up/settlement shown some increment over the period. The increment was about 771.82 ha $(0.22 \%)$ between 2003 and 2013 compared to 341.19 ha $(0.32 \%)$ between 2013 and 2017. The rate of increase in human settlement in the Nawuni Basin between 2003 and 2013 was 0.12 as against 0.08 between 2013 and 2017 (Table 2). It is evident from the analysis that whilst settlements were increasing in the basin, closed savannah land area and opened savannah lands were 
decreasing. Grassland/farmlands decreased between 2003 and 2013, but the pattern increased between 2013 and 2017. This indicates that expansion of settlement resulted in the encroachment of the closed and opened savannah land and further contributed to increase in grassland/farmland size. The rapid population growth and the increasing humandominated activities in the study catchment could have led to rapid increase in grassland/farmland and settlement cover during the period of 2013 and 2017. This puts pressure on water resources due to increase in human settlement in the Nawuni catchment leading to pollution of the rivers. It is observed that solid and liquid waste generated from settlements along the river was discharged into the water bodies. This will definitely affect the quality of water in the rivers (Ahmed and Dinye 2012) such as total coliform counts.

Water body showed some changing pattern over the period of study (Table 2). Between 2013 and 2017, there was a reduction of the area covered by water in the Nawuni catchment at 0.10 rate compared to zero rate of change between 2003 and 2013. Human activities on the land in the catchment could be contributing to siltation of the water body. The water body was reducing compared to an increasing trend of the bare land and farm lands closed to the resource. This suggests that changes in land use and land cover is impacting negatively on the water body leading to the reduction in the aerial coverage of the water body.

The study further revealed an increase in aerial coverage of closed savannah of about 32,288.02 ha representing 9.04\% from 2003 to 2013 (Table 2). There was a further increased in the closed savannah land in the second period (2013 and 2017) from 32,288.02 ha to 4341.50 ha representing $4.08 \%$. The rate of change of the closed savannah land from 2003 to 2013 was 4.91 whilst 2013 to 2017 was 1.02 . The general increased in aerial coverage of the closed savannah from 2003 to 2017 may be attributed to abandonment of lands due to soil infertility which were no longer suitable for agricultural activities in the catchment.
Bare land also showed some changes over the period of study. The aerial coverage of bare land decreased by 6954.35 ha between 2003 and 2013 in the Nawuni catchment of the WVB. This represents $1.95 \%$ decreased over the first 10 year period of the study (Table 2). The rate of decrease in the bare land from 2003 to 2013 was 1.06 as opposed to 7.96 rate of increase in the last 4 years of the study period (2013 and 2017). The rapid expansion of the bare lands could also be the reason for the reduction of the aerial extent of the opened savannah lands between 2013 and 2017. The field survey of the Nawuni catchment of the WVB revealed that the increased in the aerial coverage of the bare lands could be attributed to the conversion of some of the farmlands or fallow lands and opened savannah lands into sand winning sites. The variation could also mainly be due to rapid expansion of cultivated lands resulting from population pressure. This finding learns support from other research findings by Eleni et al. (2013) and Geist and Lambin (2002). According to Johannsen and Armitage (2010), rapid expansion of cultivated lands resulting from population growth could contribute to changing turbidity levels which the Nawuni catchment is not an exception.

\section{Water quality and LULCC in the Nawuni Catchment}

The study revealed that opened savannah land (55.9\%) is associated with high turbidity levels (229.8 NTU) as at 2003. Turbidity levels increased (184.3 NTU to 191.6 NTU) with an increasing opened savannah throughout the study period (2003 to 2017) from 191.6 NTU to 229.8 NTU. Grassland/ farmland also changes with changing turbidity levels. A decreasing grassland/farmland (37.6\% to $32.1 \%$ ) is associated with decreasing turbidity (191.6 NTU to $184.3 \mathrm{NTU}$ ), whilst an increasing grassland/farmland (32.1\% to $36.2 \%)$ otherwise shows increasing turbidity (184.3 NTU to 229.8 NTU) levels between 2003 and 2013 and between 2013 and 2017, respectively (Fig. 8).
Fig. 8 Relationship between changing turbidity and LULCC in the Nawuni Catchment

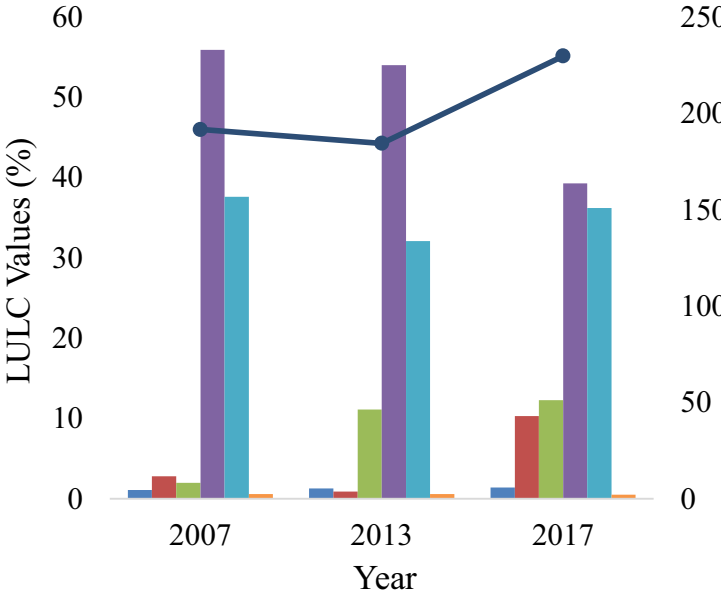


Moreover, closed savannah (2\% to $11.1 \%$ ) increases with a decreasing turbidity (191.6 NTU to 184.4 NTU) from 2003 to 2013 and further increased in closed savannah $(11.1 \%$ to $10.3 \%$ ) from 2013 to 2017 led to an increased in turbidity (184.4 NTU to 229.8 NTU). Decreasing bare land like any of the land use and land cover types is noted to be associated with a decreasing turbidity from 2003 to 2013, whilst an increasing bare land was found to be associated with an increasing turbidity (Fig. 8). The reason for the association could be due to exposure of the land to surface run-off. Surface run-off is typically associated with increasing turbidity in surface water bodies. Transformation of vegetated land into bare land is reported to have resulted in high levels of turbidity (Zamani et al. 2012). Bare land usually results from inappropriate human activities which affects river water quality (Fig. 8). The aerial coverage values of the water body (0.6\% in both 2003 and 2013 and $0.5 \%$ in 2017) were very small and show a decreasing pattern throughout the period of study unlike total coliform which reduced between 2003 and 2013 and increased between 2013 and 2017. Settlement increased throughout the study period unlike turbidity which decreased during the first period and increased during the second period. Settlement increased throughout the period of study between 2003 and 2017 which is associated with increasing turbidity levels from 191.64 NTU to 229.80 NTU.

Correlation and multiple regression analyses conducted to examine the relationship between turbidity and various land use and cover types (Table 3 ) indicated some levels of interactions. The study revealed significant positive relationship between turbidity and built up/settlement $(r=0.617$, $P=0.029)$. There was also significant and positive relationship between turbidity and closed savannah $(r=0.638$, $P=0.024$ ). The multiple regression model (Table 3 ) with the two predictors produced $R^{2}=0.409, F(2,7)=2.42$, $P=0.159$. The $R^{2}=0.409$ implies that settlement and closed savannah contributed $40.9 \%$ change in turbidity levels. The settlement and closed savannah have insignificant positive regression weight (Table 3), which means that the two predictors are insignificant contributors to the regression model. The positive regression weight implies that when settlement increases there will be an increase in turbidity levels and the reverse is true. However, the negative regression weight of closed savannah implies that when closed savannah increases then turbidity levels will decrease and when closed savannah decreases, turbidity levels increased. The presence of vegetation in an area, especially water catchment, is noted to reduce runoffs and soil erosion, thereby reducing turbidity. This has been confirmed by a recent study by McMahon et al. (2020) that vegetation could reduce riverbank erosion, and therefore contribute to reducing turbidity.

Figure 9 presents the relation between changing ammonia trends and land use and land cover changes in the study area. It is clear from the figure that opened savannah decreased between 2003 and 2013 (from 55.9 to 54\%). At the same period (2003 and 2013), ammonia levels increased (from $0.99 \mathrm{mg} / \mathrm{l}$ to $1.87 \mathrm{mg} / \mathrm{l})$. Further falls in the aerial coverage of opened savannah between 2013 and 2017 (54\% to 39.3\%) is associated with continuous increase in ammonia levels
Table 3 Relationship between changing turbidity levels and land use and land cover changes (LULCC)

Fig. 9 Ammonia variation and land use and land cover changes

\begin{tabular}{lclll}
\hline Variable & Mean \pm SD & $\begin{array}{l}\text { Correlation with } \\
\text { turbidity }\end{array}$ & \multicolumn{2}{l}{$\begin{array}{l}\text { Multiple regression } \\
\text { weights }\end{array}$} \\
\cline { 4 - 5 } & & & B & Sig. \\
\hline Constant & $4570.087 \pm 240.589$ & $0.029^{*}$ & 248.77 & 0.882 \\
Settlement & $33,381.260 \pm 8093.25$ & $0.024^{*}$ & $0.008^{* *}$ & 0.579 \\
Closed savannah & & $-0.066^{\text {ns }}$ & 0.886 \\
\hline
\end{tabular}

$R^{2}=0.409$, ns $=$ Not significant, $b=$ Unstandardized coefficients

$* P<0.05 ; * * P<0.01$

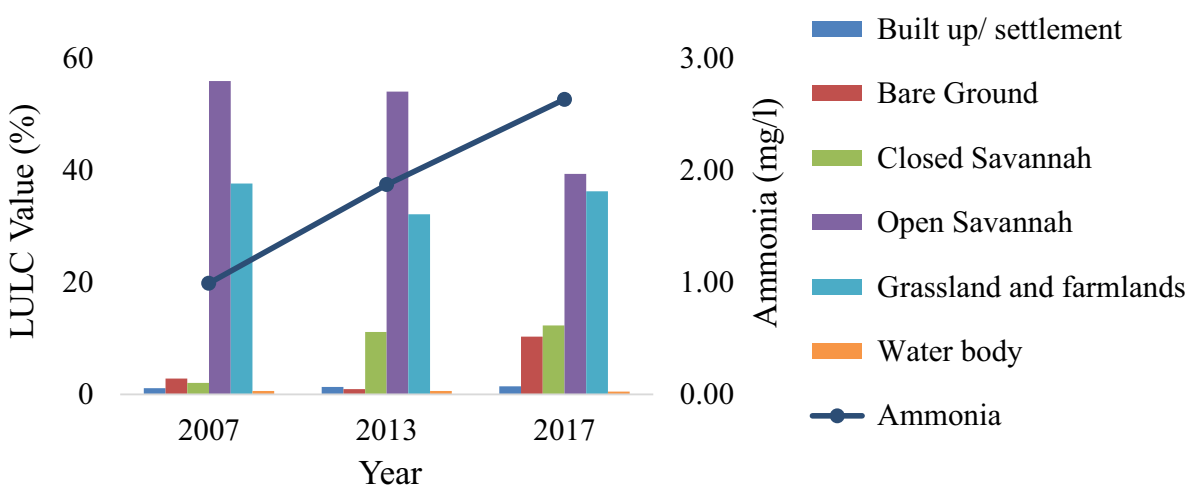


(1.87 $\mathrm{mg} / \mathrm{l}$ to $2.63 \mathrm{mg} / \mathrm{l})$. It was also clear that an increased in grassland/farmland (32.1\% to $36.2 \%)$ between 2013 and 2017 has resulted to an increased in ammonia levels from $1.87 .3 \mathrm{mg} / \mathrm{l}$ to $2.63 \mathrm{mg} / \mathrm{l}$ (Fig. 9). Ammonia is generally associated with agricultural land use, and this reflects the reality on the ground as many of the farmers in the catchment of the Nawuni apply both organic and inorganic fertilizers to their crops and this might have accounted for this trend. Gildea (2000) reported a similar trend in his study where watersheds with more agricultural areas tend to be associated with increasing deposition of phosphorus and nitrogen which were key ingredients in fertilizer formulation.

Furthermore, an increased in bare land between 2013 and 2017 was found to be associated with an increasing ammonia level (Fig. 9). The aerial coverage of the water body was $0.6 \%$ between 2003 and 2013 and $0.5 \%$ between 2013 and 2017. The water body decreases throughout the study period with increasing ammonia levels. The reason for the decrease in water body could be attributed to the silting up of the water body due to poor farming and sand winning activities. This corroborates the findings of similar study by Karikari and Ansa-Asare (2006) that large quantities of top soil end up in the river after heavy rains due to human land use activities such as poor farming activities which results in siltation. It is also a known fact that farmers around the catchment apply fertilizers to their crops and also rear animals such as ruminants. Such farming activities lead to the generation of ammonia which may end up into the water body thereby increasing the ammonia levels in the water body.

The correlation analysis (Table 4 ) revealed a significant and positive relationship between ammonia and built up/ settlement ( $r=0.691, P=0.013$ ). There was also a significant and positive relationship between ammonia and grassland/farmland ( $r=0.776, P=0.004)$, whilst the relationship between ammonia and closed savannah was, however, negatively significant ( $r=-0.660, P=0.019)$. The multiple regression model with the two predictors produced $R^{2}=0.725, F(2,7)=9.227, P=0.011$ (Table 4). The $R^{2}$ implies that grassland/farm land and settlement contributed $72.5 \%$ change in ammonia levels. Grassland/farmland and settlement have significant and positive regression weight of 0.040 and 0.030 , respectively (Table 4). This means that the two predictors are significant contributors to the regression model. The positive regression weight implies that when grassland/farm land and settlement increase, ammonia levels increase as well and vice versa.

Figure 10 presents the relation between changing total coliform levels and land use and land cover changes in the study area. The study showed a decreased in opened savannah land (from 55.9 to $39.3 \%$ ) resulted in increasing total coliform levels (1148. $67 \mathrm{NTU}$ to $2758.33 \mathrm{NTU}$ ) between 2003 and 2017. Interestingly, an increase in grassland/farmland $(32.1 \%$ to $36.2 \%)$ is associated with a decrease in total coliform (4843.26 NTU to 2758.33 NTU) during the period of study (Fig. 10).
Table 4 Correlation and multiple linear regression analyses between ammonia and LULCC

Fig. 10 Total coliform variation in relation to LULCC in Nawuni Catchment

\begin{tabular}{lclll}
\hline Variable & Mean \pm SD & $\begin{array}{l}\text { Correlation with } \\
\text { ammonia }\end{array}$ & \multicolumn{2}{l}{$\begin{array}{l}\text { Multiple regression } \\
\text { weights }\end{array}$} \\
\cline { 4 - 5 } & & & $\mathrm{B}$ & Sig. \\
\hline Constant & $121,037.200 \pm 3862.700$ & $0.019^{* *}$ & 5.140 & 0.374 \\
Grass/farmland & $4570.087 \pm 240.589$ & $0.013^{* *}$ & $8.655^{\text {ns }}$ & $0.040^{*}$ \\
Settlement & & $0.002^{* *}$ & $0.030^{*}$ \\
\hline
\end{tabular}

$R^{2}=0.725, \mathrm{~ns}=$ Not significant, $b=$ Unstandardized coefficients

$* P<0.05 ; * * P<0.01$

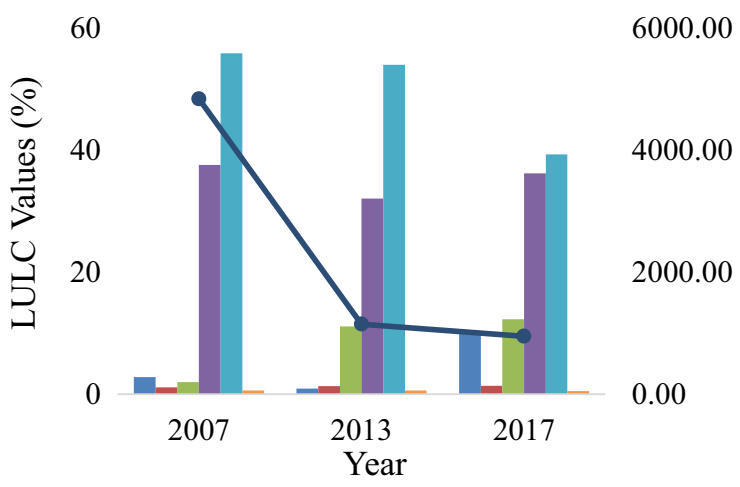


Table 5 Correlation and multiple linear regression analyses between total coliform and LUCC

\begin{tabular}{lclrl}
\hline Variable & Mean \pm SD & $\begin{array}{l}\text { Correlation with total } \\
\text { coliform }\end{array}$ & \multicolumn{2}{l}{$\begin{array}{l}\text { Multiple regression } \\
\text { weights }\end{array}$} \\
\cline { 4 - 5 } & & & $B$ & Sig. \\
\hline Constant & & & $32,063.758$ & $0.338^{\text {ns }}$ \\
Grass/farmland & $121,037.200 \pm 3862.7$ & $0.034^{*}$ & $0.333^{\text {ns }}$ & $0.211^{\text {ns }}$ \\
Settlement & $33,381.260 \pm 8093.25$ & $0.036^{*}$ & $0.154^{\text {ns }}$ & $0.223^{\text {ns }}$ \\
\hline
\end{tabular}

$R^{2}=0.487, \mathrm{~ns}=$ Not significant, $b=$ Unstandardized coefficients

$* P<0.05 ; * * P<0.01$
Moreover, bare land like most of the land use types discussed earlier decreased alongside total coliform between 2003 and 2013 and increasing bare land was found to be associated with an increasing total coliform between 2013 and 2017 (Fig. 10). Settlement increased with total coliform throughout the study period (between 2003 and 2017).

A correlation analysis (Table 5) revealed significant relationships between the LULC types and water quality parameters. Closed savannah had significant and positive relationship with total coliform $(r=0.590, P=0.036)$. There is also significant and positive relationship between total coliform and grassland/farmland $(r=0.597, P=0.034)$.

The multiple regression model (Table 5) with the two predictors produced $R^{2}=0.487, F(2,7)=3.325, P=0.097$. The $R^{2}(0.487)$ implies that grassland/farmland and settlement contributed $48.7 \%$ change in total coliform levels. The grassland/farmland has insignificant and positive regression weight whilst settlement also has positive but insignificant regression weight (Table 5). The positive regression weight implies that when grassland/farmland and settlement increase total coliform will also increase and when grassland/farmland and settlement decrease total coliform levels decrease as well. Thus, the conversion of forested or vegetated lands into farmlands/grassland and settlements will have negative impact on water quality, especially the increase in total coliform. This finding is in consonant with that of Gildea (2000) who found that watersheds with more urban land were associated with declining water quality of which total coliform among the water quality parameters.

\section{Conclusions}

The study assessed the relationship between river water quality and land use and land cover changes in the Nawuni Catchment. Surface water quality of the WVB was assessed over the study period to determine state of the water which showed an interesting outcome. There was general increase in both turbidity and ammonia and a decrease in total coliform of water in the Nawuni Catchment.
It was also evident that land cover and land use changes have taken place in the Nawuni catchment of the WVB over the 15-year period. There was an increment in grassland/ farmlands, settlements, bare land as well as closed savannah as opposed to a decreasing water body and opened savannah land areas.

Correlation and multiple linear regression analyses between land use and land cover changes and surface water quality in the study area revealed that changing land use and land cover in the catchment brought about changing river water quality in terms of turbidity, ammonia and total coliform.

Surface water quality changes over time, and since the resource is essential for the region and Ghana as a whole, proper land use planning and management in the catchment by the WRC, VBA and GWCL and other stakeholders are recommended to reverse and sustain the water resources in the area. Land uses which threat the quality water in the area should be discouraged.

Acknowledgements We are grateful to the management of GWCL, Tamale, especially Mr. Nicolas Okyere, the Manager of GWCL laboratory, Tamale, and the Lab Assistant, Mr. Augustine Addo, for providing us relevant water quality data for the research work. I also thank Mr. Emmanuel Yeboah, EPA, Bolgatanga.

Funding The research was self-financed by the authors.

\section{Compliance with ethical standards}

Conflict of interest There is no competing interest among authors of this research article.

Open Access This article is licensed under a Creative Commons Attribution 4.0 International License, which permits use, sharing, adaptation, distribution and reproduction in any medium or format, as long as you give appropriate credit to the original author(s) and the source, provide a link to the Creative Commons licence, and indicate if changes were made. The images or other third party material in this article are included in the article's Creative Commons licence, unless indicated otherwise in a credit line to the material. If material is not included in the article's Creative Commons licence and your intended use is not permitted by statutory regulation or exceeds the permitted use, you will need to obtain permission directly from the copyright holder. To view a copy of this licence, visit http://creativecommons.org/licenses/by/4.0/. 


\section{References}

Abdul-Razak A, Asiedu AB, Entsua-Mensah REM, deGraft-Johnson KAA (2010) Assessment of the water quality of the Oti river in Ghana. West Afr J Appl Ecol 15(1):45-60

Ahmed A, Dinye R (2012) Impact of land use activities on Subin and Aboabo Rivers in Kumasi Metropolis. J Water Resour Environ Eng 4(7):241-251

Awotwi A, Yeboah F, Kumi M (2015) Assessing the impact of land cover changes on water balance components of White Volta Basin in West Africa. Water Environ J 29(2):259-267

Ayisi CL, Quarshie B, Cobbina SJ (2014) Raw water quality change and cost implication; a case study of Dalun Headwork's. Int J Water Res 2(1):16-20

Ayivor JS, Gordon C (2012) Impact of land use on river systems in Ghana. West Afr J Appl Ecol 20(3):83-95

Baatuuwie BN (2015) Multi-dimensional approach for evaluating land degradation in the Savannah Belt of the White Volta Basin (Unpublished thesis). KNUST, Kumasi

Bakobie N, Sukairazu I, Duwiejuah AB (2015) Assessment of dam water quality in three selected communities in SaveluguNanton municipality, Ghana. Int Res J Public Environ Health 2(12):225-231

Bossio D, Geheb K, Critchley W (2010) Managing water by managing land: addressing land degradation to improve water productivity and rural livelihoods. Agric Water Manag 97(4):536-542

Chaudhry FN, Malik MF (2017) Factors affecting water pollution: a review. J Ecosyst Ecography 7(225):1-3

Chu HJ, Liu C, Wang C (2013) Identifying the relationships between water quality and land cover changes in the Tseng-Wen Reservoir Watershed of Taiwan. Int J Environ Res Public Health 10:478-489

Ding J, Yuan J, Lan F, Qi L, Qiuzhi P, Muyi K (2015) Impacts of land use on surface water quality in a subtropical river basin: a case study of the Dongjiang River Basin, South Eastern China. J Water 7(8):4427-4445

Doke AD, Julia MG (2014) Estimation of human health risk from exposure to methylmercury via fish consumption in Ghana. J Health Pollut 4(6):18-25

Eleni Y, Wagner W, Exner-Kittridge M, Legesse D, Blöschl G (2013) Identifying land use/cover dynamics in the Koga catchment, Ethiopia, from multi-scale data, and implications for environmental change. ISPRS Int J Geo-Inf 2(2):302-323

Ellis E, Pontius R (2007) Land use and land cover change. In: Cleveland CJ (ed) Encyclopedia of Earth. Environmental Information Coalition, National Council for Science and the Environment, Washington, DC

Geist H, Lambin E (2002) Proximate causes and underlying driving forces of tropical deforestation. Biosciences 52(2):143-150

Gildea JJ (2000) Relationships between land use, land-use change, and surface water quality trends in Virginia. Master Science Thesis submitted to the Faculty of the Virginia Polytechnic Institute and State University. Blacksburg, Virginia

Gyamfi ET, Ackah M, Anim AK, Hanson JK, Kpattah L, Enti-Brown S, Nyarko ES (2012) Chemical analysis of potable water samples from selected suburbs of Accra, Ghana. Proc Int Acad Ecol Environ Sci 2(2): 118-127

Gyawu-Asante FN (2012) Physico-chemical quality of water sources in the gold mining areas of Bibiani (unpublished thesis). KNUST, Kumasi

International Union for Nature Conservation (IUCN-BRAO) (2012) Water audit of the Volta Basin update report

Issaka S, Ashraf MA (2017) Impact of soil erosion and degradation on water quality: a review. Geol Ecol Landsc 1(1):1-11
Johannsen SS, Armitage P (2010) Agricultural practice and the effects of agricultural land -use on water quality. Fresh Water Forum 28:45-59

Julian JP, Beurs KM, Owsley B, Davies-Colley RJ, Ausseil AGE (2016) River water quality changes in New Zealand over 26 years (1989-2014): response to land use and land disturbance. Hydrol Earth Syst Sci Discuss 21:1-69

Karikari AY, Ansa-Asare OD (2006) Physico-chemical and microbial water quality assessment of Densu River of Ghana. West Afr J Appl Ecol. https://doi.org/10.4314/wajae.v10i1.45701

Ketata M, Gueddari M, Bouhlila R (2011) Use of geographical information system and water quality index to assess groundwater quality in El Khairat deep aquifer (Enfidha, Central East Tunisia). Arab J Geosci 5(6):1379-1390

Khan HH, Khan A, Ahmed S, Perrin J (2011) GIS-based impact assessment of land-use changes on groundwater quality: study from a rapidly urbanizing region of South India. Environ Earth Sci 63(6): 1289-1302

Khan A, Khan HH, Umar R (2017) Impact of land-use on groundwater quality: GIS-based study from an alluvial aquifer in the western Ganges basin. Appl Water Sci 7(8):4593-4603

Kpieta AB, Laari BP (2014) Small-scale dams water quality and the possible health risk to users of the water in the Upper West Region of Ghana. Eur Sci J ESJ 10(14):249-270

Le QB, Nkonya E, Mirzabaev A (2014) Biomass productivity-based mapping of global land degradation hotspots. ZEF-discussion papers on development policy No. 193. University of Bonn

Li X, Nian Y, Zhou J, Hu X (2014) Impact of land use change on water resource allocation in the middle reaches of the Heihe River Basin in North Western China. J Arid Land 6(3):273-286

Matshakeni Z (2016) Effects of land use changes on water quality in Eerste River, South Africa (Unpublished thesis). University of Zimbabwe, Zimbabwe

McCartney M, Forkuor G, Sood A, Amisigo B, Hattermann F, Muthuwatta L (2012) The water resource implications of changing climate in the Volta River Basin, vol 146. IWMI, Colombo

McMahon MJ, Olley MJ, Brooks PA, Smart CRJ, Stewart-Koster B, Venables NW, Curwen G, Kemp J, Stewart M, Saxton N, Haddadchi A, Stout CJ (2020) Vegetation and longitudinal coarse sediment connectivity affect the ability of ecosystem restoration to reduce riverbank erosion and turbidity in drinking water. Sci Total Environ 707:135904. https://doi.org/10.1016/j.scito tenv.2019.135904

Muke M, Haile B (2018) Land-use/cover change analysis using remote sensing techniques in the landscape of Majang Zone of Gambella Region, Ethiopia. Afr J Environ Sci Technol 12(4):141-149

Mul M, Obuobie E, Appoh R, Kankam K, Bekoe-obeng E, Amisigo B, Mccartney M (2015) water resources assessment of the Volta River Basin, vol 166. IWMI, Colombo

Muluneh A, Arnalds O (2011) Synthesis of research on land use and land cover dynamics in the Ethiopian highlands. Unpublished thesis. Hawassa University, Reykjavik, Iceland

Nabeela F, Azizullah A, Bibi R, Uzma S, Murad W, Shakir SK (2014) Microbial contamination of drinking water in Pakistan-a review. Environ Sci Pollut Res 21(24):13929-13942

Nagaraju A, Sunil Kumar K, Thejaswi A (2014) Assessment of ground water quality for irrigation: a case study from Bandalamottu lead mining area, Guntur district, Andhra Pradesh. Appl Water Sci $4: 385-396$

Nkonya E, Gerber N, Von Braun J, De Pinto A (2011) Economics of land degradation: the costs of action versus inaction, IFPRI issue brief no. 68

Nkonya E, Mirzabaev A, von Braun J (2016) Economics of land degradation and improvement: an introduction and overview. In: Nkonya E, Mirzabaev A, von Braun J (eds) Economics of land degradation and improvement - a global assessment

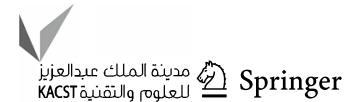


for sustainable development. Springer, Cham. https://doi. org/10.1007/978-3-319-19168-3_1

Olusola A, Onafeso O, Durowoju OS (2018) Analysis of organic matter and carbonate mineral distribution in shallow water surface sediments. Osun Geogr Rev 1(1):106-110

Pullanikkatil D, Palamuleni L, Ruhiiga T (2015) Impact of land use on water quality in the Likangala Catchment, Southern Malawi. Afr J Aquat Sci 40(3):277-286

Rawat JS, Manish K (2015) Monitoring land use/cover change using remote sensing and GIS techniques: a case study of Hawalbagh block, district Almora, Uttarakhand, India. Egypt J Remote Sens Space Sci 18(1):77-84

Rientjes THM, Haile AT, Kebede E, Mannaerts CMM, Habib E, Steenhuis TS (2011) Changes in land cover, rainfall and stream flow in Upper Gilgel Abbay catchment, Blue Nile basin-Ethiopia. Hydrol Earth Syst Sci 15(6):1979-1989

Shabbir R, Ahmad SS (2015) Use of geographic information system and water quality index to assess groundwater quality in Rawalpindi and Islamabad. Arab J Sci Eng 40(7):2033-2047

UN (United Nations) (2014) World urbanization prospects: the 2014 revision, highlights. Department of Economic and Social Affairs, population division

UNEP-GEF Volta Project (2010) Volta basin transboundary diagnostic analysis: National report Ghana. UNEP/GEF/Volta/NR GHANA $1 / 2010$
UNEP-GEF Volta Project (2013) Volta basin transboundary diagnostic analysis: National report Ghana. UNEP/GEF/Volta/NR GHANA 1/2010. United Nations Environment Programme (UNEP), Accra, Ghana

Wagner PD, Kumar S, Schneider K (2013) An assessment of land use change impacts on the water resources of the Mula and Mutha Rivers catchment upstream of Pune, India. Hydrol Earth Syst Sci 17(6):2233-2246

Water Resources Commission (WRC) (2012) White Volta River Basin-National Integrated Water Resources Management (IWRM) Plan

WHO (2011) Guidelines for drinking-water quality. World Health Organ 216:303-304

Zamani M, Sadoddin A, Garizi AZ (2012) Assessing land-cover/landuse change and its impacts on surface water quality in the Ziarat catchment, Golestan Province-Iran. Hydrol Curr Res 4(3):1-5

Publisher's Note Springer Nature remains neutral with regard to jurisdictional claims in published maps and institutional affiliations. 